\title{
Monitoring and Implementation of Children's Rights
}

\author{
Julia Sloth-Nielsen
}

\section{Contents}

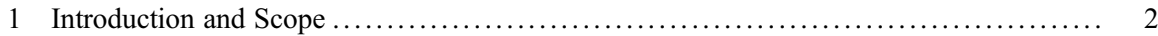

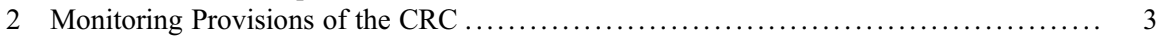

2.1 State Party Reporting and the CRC Committee $\ldots \ldots \ldots \ldots \ldots \ldots \ldots \ldots \ldots \ldots \ldots \ldots \ldots$

2.2 Content of Reports: The Revised Guidelines .............................. 4

2.3 The Reporting Process .............................................. 8

2.4 Assessment of the Monitoring Function of the CRC Committee Through

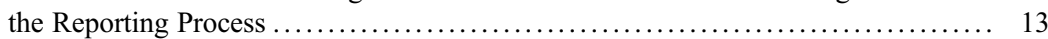

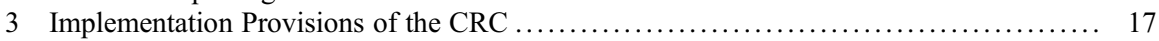

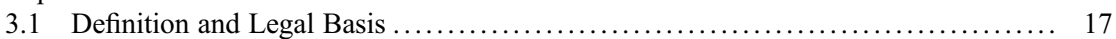

3.2 Specific Areas of General Implementation .............................. 18

3.3 Assessment of the Implementation of the CRC and the Rights it Provides For ..... 24

4 Monitoring of Children's Rights Implementation via Other Mechanisms $\ldots \ldots \ldots \ldots \ldots \ldots \ldots 25$

4.1 Special Mandate Holders and Monitoring of the Use of Child Soldiers at

UN Security Council Level ....................................... 25

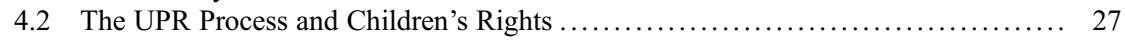

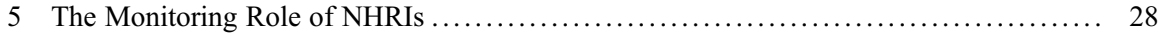

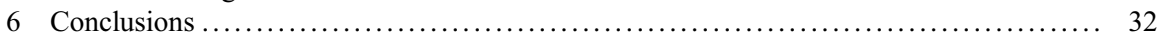

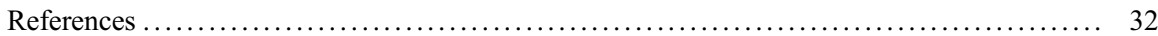

\section{Abstract}

This chapter reviews the monitoring, and requirements for domestic implementation, of the rights contained in the Convention on the Rights of the Child (hereafter CRC). It explains the State party reporting system established under Article 44 of the CRC and the consideration of these reports by the United Nations Committee on the Rights of the Child (CRC Committee), established

\footnotetext{
J. Sloth-Nielsen $(\square)$

Public Law and Jurisprudence, University of the Western Cape and Professor of Children's Rights in the Developing World, Leiden University, Bellville, South Africa

e-mail: jsloth-nielsen@uwc.ac.za
} 
under Article 43 of the CRC. Next, the discussion turns to implementation, based largely on the requirements of General Comment No. 5 (2003) on General Measures of Implementation. Throughout these sections, extensive reference is made to subsidiary documents of the CRC Committee such as working methods guidelines, rules of procedure, and General Comments. The 2016 General Comment No. 19 of the CRC Committee (on public budgeting for the realization of children's rights (Article 4)) receives some attention. A brief section which follows focuses on the monitoring role played by relevant special mandate holders, the monitoring mechanism established by the UN in relation to the use of child soldiers, and the Universal Periodic Review (UPR) process as an element of monitoring of children rights (however, the chapter does not traverse the interplay between children's rights and the work of the nine other treaty bodies, for reasons of space and coherence). The final and fifth section explores the role of National Human Rights Institutions (NHRIs) in monitoring children's rights.

\title{
1 Introduction and Scope
}

\begin{abstract}
Accountability for human rights now encompasses a wide spectrum of activities aimed at translating the international human rights obligations states have accepted into domestic policies, laws, procedures and practices, and rendering them justiciable or enforceable by the courts and other adjudicatory or monitoring bodies. The recognition that human rights entail both positive and negative obligations and that duty bearers include states and non-state actors has also meant that accountability means much more than policing state compliance with its negative obligations. (Chirwa 2015)
\end{abstract}

This chapter deals with the diverse aspects related to monitoring and implementation of international children's rights as contained in the global treaty, the UN $\mathrm{CRC}$, and its optional protocols. To a very limited extent, the regional treaty, the African Charter on the Rights and Welfare of the Child, will also be touched upon, where relevant. The chapter proceeds from that standpoint that the basic obligation for States parties which have ratified the above treaties that is incurred under human rights law is fourfold: the obligation to respect the treaty provisions; the obligation to protect the rights enshrined therein and, more narrowly, to protect individuals within their jurisdiction from breaches of their rights by the state or by non-state actors; the obligation to promote the rights (by raising awareness, publicizing them, and creating a human rights culture); and to fulfil the rights to the benefit of the rights holder beneficiaries (Wallace and Ortega-Martin 2013).

In principle, all rights are indivisible, interrelated, and interdependent. However, as will emerge, it is apparent that some rights are immediately enforceable, while others are subject to progressive realization over time. This naturally has an impact upon the nature of the implementation obligation and may also determine some characteristics of monitoring. This chapter also proceeds from a premise that monitoring chiefly involves external oversight by the CRC Committee of States parties' compliance with their children's rights obligations under international law. There is, 
it is conceded, also a view that internal monitoring by States of the implementation of their obligations is a reality, insofar as "self-monitoring can be defined as an internal accountability process by which state agencies charged with the responsibility of implementing children's rights evaluate themselves against their own standards, benchmarks and targets and those set by external or independent agencies, national or international. Self-monitoring can be performed by a specific state official, office, unit, institution or department with specific or general oversight powers or with the dual mandate to implement and monitor progress on implementation" (Chirwa 2015: 16). However, the starting point of this chapter is the external monitoring function of the CRC Committee, since aspects of self-monitoring are dealt with in subsequent sections. Civil society monitoring of the performance of States parties in implementing children's rights is covered only to the extent that civil society is involved in the treaty body reporting process and not in relation to domestic monitoring.

Implementation, on the other hand, is the domestic application of the CRC (and/or the ACRWC). Although national implementation may be contextually and culturally determined, and may therefore vary from State party to State party, some supranational norms and principles related to implementation have emerged, chiefly through the General Comments of the CRC Committee and through analysis of common threads which run throughout Concluding Observations issued by the Committee in response to State party reports.

Therefore, this chapter will first consider the question of monitoring, before proceeding to consider the CRC implementation provision(s) and thereafter the key general principles related to implementation of children's rights. A section on monitoring of children's rights via other UN mechanisms follows, and the chapter concludes with a brief analysis of the place of national human rights institutions (NHRIs) in the monitoring and implementation framework.

\section{Monitoring Provisions of the CRC}

\subsection{State Party Reporting and the CRC Committee}

The monitoring provisions of the CRC are to be found chiefly in Article 44, which established the system of State party reporting, which is common to all other UN human rights treaties. The reports are considered by the CRC Committee, established under Article 45 of the treaty. The Committee consists of 18 members elected by the UN, with 9 seats becoming available every 2 years (Sahovic et al. 2013: 339). (The initial provision in Article $43 \mathrm{CRC}$ for 10 members was increased to 18 in 2003 following a decision by the conference of States parties). Members are supposed to be experts in one or other field of children's rights, such as law, education, or child psychology. The Committee must be broadly representative of the different regions and legal cultures of the world. Of late, elections have been highly contested with many more candidates being nominated than there are vacancies. Committee members serve in their personal capacity and not as representatives of the government that 
nominated them. A term is 4 years, but reelection is possible, and several current members are serving a second or subsequent term. The Bureau of the CRC Committee (Chair, four Vice-Chairs, and one Rapporteur) is elected by the members themselves, with a recent commitment to rotating the Chair's seat among the world regions. The Committee has at various points adopted rules of procedure which govern, among others, the conduct of meetings, voting rights, the elections of officers of the Committee, and what is to happen if a member dies or resigns (Sahovic et al. 2013: 341).

The CRC is the most widely ratified international human rights treaty with 196 States Parties. All UN Member States of the UN have ratified with the exception of the United States which signed the treaty in 2000 but has not introduced the necessary legislation into the Houses to complete the process. Four nonmember states of the UN have ratified the $\mathrm{CRC}$, being the Holy See, Niue, the Cook Islands, and the State of Palestine.

After submitting an initial report within 2 years of ratification, State parties are thereafter required to report every 5 years. At the time of writing, all States parties that had ratified the CRC save two had submitted their initial report (Report of the Secretary General 2016), the two concerned being Tonga and the State of Palestine. Many countries have delayed submitting reports or submitted combined periodic reports (e.g., second, third, and fourth combined reports). Nevertheless, the CRC stands out as the UN treaty which has elicited the most State party reports and, on the most consistent basis, by comparison to other treaties. The volume of reports received by the $\mathrm{CRC}$ committee has led to the Committee from time to time sitting in two chambers, enabling it to consider a greater number of submitted reports during sessions and whittle away at backlogs that have arisen (Sahovic et al. 2013: 362). Nevertheless, there remains a lead time of more than a year (or 2) after submission of a State party report before the responsible government's session before the Committee is scheduled. As at 27 September 2016, the Committee had received 502 initial and periodic reports, including combined periodic reports, submitted pursuant to Article 44 of the CRC. Furthermore, the Committee had received 109 initial reports and 2 periodic reports under the Optional Protocol to the Convention on the involvement of children in armed conflict (hereafter OPAC) and 98 initial reports and 2 periodic reports under the Optional Protocol to the Convention on the sale of children, child prostitution, and child pornography (hereafter OPSC) (Report of the Secretary General 2016).

\subsection{Content of Reports: The Revised Guidelines}

The reports relating to the $\mathrm{CRC}$ are to be compiled in accordance with the CRC Committee's Revised Guidelines for periodic reports (Revised Guidelines 2015), which were developed in accordance with the harmonized guidelines on reporting under the international human rights treaty bodies, including guidelines on a Common Core Document (CCD) and treaty-specific documents (HRI/GEN/2/Rev.6, chap. I), last revised in 2009; State parties are advised that the Revised Guidelines 
should be applied in conjunction with the guidelines for the preparation and submission of the common core document contained in the harmonized guidelines.

Par 7 of the Revised Guidelines explains that " $[t]$ he common core document is an integral part of the reports submitted to the Committee in accordance with the harmonized guidelines. It should contain general information about the reporting State; the general framework for the protection and promotion of human rights; and information on non-discrimination, equality and effective remedies. It should not exceed 42000 words, and it should be updated with relevant information upon submission of a treaty specific report. The treaty specific report should not repeat the information contained in the common core document (unless one has not been submitted)." The time-saving idea is that the same document can be used for all treaty reports for a country.

Prior to the Revised Guidelines, reporting under the CRC and the two Optional Protocols was a separated process. The Revised Guidelines seek to synchronize the reporting cycle as far as periodic reports are concerned, providing that periodic reports under the CRC must report on implementation of the CRC and of the Optional Protocols (with some exceptions, e.g., for the United States, which has not ratified the $\mathrm{CRC}$ but has ratified the Optional Protocols: hence, the OPAC reporting guidelines of 2007 and the OPSC guidelines of 2006 would then be applicable, rather than the Revised Guidelines). There are also other exceptions to the general applicability of the Revised Guidelines to the envisaged merged reporting process, e.g., where an initial report has not yet been submitted under the Optional Protocols.

Par 12 of the Revised Guidelines requires that the treaty-specific report should contain information on the implementation of the provisions of the Convention and of the Optional Protocols, if applicable, in relation to relevant General Comments of the Committee, as well as information of a more analytical nature on how laws, legal systems, jurisprudence, the institutional framework, policies, and programs have an impact on children within the jurisdiction of the State party, according to their different age groups, from early childhood to adolescence, and their special needs. The treatyspecific report should not exceed 21,200 words and should address the Committee's previously issued Concluding Observations (COs). The State party should in its report indicate progress made and challenges encountered in achieving full respect for the provisions of the Convention and the Optional Protocols, if applicable.

The Revised Guidelines (as did their predecessors) cluster the CRC Rights. Clustering was adopted in the early days of the CRC Committee to avoid lengthy reports in which all 40 substantive articles of the CRC are covered seriatim. It was also intended to highlight the interconnectedness of rights. However, it does ensure that ALL CRC rights are covered one way or another - States parties cannot elect to leave out or omit rights, which would have resulted in gaps.

There are now 11 themes (or clusters), namely, General Measures of Implementation; Definition of a Child; General Principles; Civil Rights and Freedoms; Violence against Children; Family Environment and Alternative Care; Disability, Basic Health, and Welfare; Education, Leisure, and Cultural Activities; Special Measures of Protection; Follow-up to the Optional Protocol to the Convention on the Rights of the Child on the sale of children, child prostitution, and child pornography; and 
Follow-up to the Optional Protocol to the Convention on the Rights of the Child on the involvement of children in armed conflict (Revised Guidelines 2015).

"General Measures of Implementation" includes (among others) such issues as domestication of the CRC through law reform, reporting on whether a comprehensive national strategy and plan for implementing children's rights, overall coordination of the implementation of the $\mathrm{CRC}$ within the respective government structure, budgeting for children, the establishment and functioning of a national human rights institution with an appropriate mandate to monitor the domestic implementation of CRC rights, and cooperation with civil society and measures to make the contents of the CRC widely known exist. General Comment No. 16 (2013) on State obligations regarding the impact of the business sector on children's rights may also require explanation under this heading, as States must report under this heading on their oversight of businesses that may impact the enjoyment of children's rights (see Revised Guidelines par 21). Under this cluster, States parties should also take into account the Committee's General Comment No. 2 (2002) on the role of independent national human rights institutions in the promotion and protection of the rights of the child and General Comment No. 5 (2003) on General Measures of Implementation of the Convention on the Rights of the Child.

Under the heading "Definition of a Child," the State party report is supposed to cover relevant and up-to-date information with respect to Article 1 of the Convention concerning the definition of the child in its domestic laws and regulations. If the age of majority is below the age of 18 years, the State party should indicate how all children benefit from protection and enjoy their rights under the Convention up to the age of 18 years. The State party should indicate the minimum age for marriage for girls and boys in its legislation.

A consideration of the CRC's General Principles should then follow. These are the well-known "pillars" of the CRC, as identified by the first incumbent CRC Committee, on which the fulfilment of all other CRC rights rest. They are the right not to be discriminated against (Art. $2 \mathrm{CRC}$ ); the primacy of the best interests of the child (Art. $3 \mathrm{CRC}$ ); the child's right to life, survival, and development (Art. 6); and respect for the views of the child (Art. 12). Under the first, the CRC Committee is desirous of receiving information about measures to combat gender-based discrimination and to ensure the full enjoyment of their rights by children with disabilities, children belonging to minorities, and indigenous children (par 24 Revised Guidelines). As regards Articles 3 and 12, par 25 of the Revised Guidelines requests the provision of information on legislative, judicial, administrative, or other measures in force to enable these principles to be furthered. The right to life, survival, and development includes information pertaining to guarantees that capital punishment is not imposed for offences committed by persons under 18 years, to extrajudicial killings of children, and to child suicide prevention (as well as measures on other relevant issues affecting the right to life, survival, and development of children) (Revised Guidelines par 27). Under this cluster, States parties should take into account the Committee's General No. 14 (2013) on the right of the child to have his or her best interests taken as a primary consideration, No. 12 (2009) on the right of the child to be heard, and No. 11 (2009) on indigenous children and their rights under the Convention. 
The cluster "Civil Rights and Freedoms" covers reporting under Articles 7, 8, and 13-17 of the CRC. The (new) cluster "Violence against Children" spans several interrelated themes: abuse and neglect (Art. 19 CRC); measures to prohibit and eliminate all forms of harmful practices, including, but not limited to, female genital mutilation and early and forced marriages (Art. 24, para. $3 \mathrm{CRC}$ and Joint General Comment No. 18 on Harmful Traditional Practices (2014)); sexual exploitation and sexual abuse (Art. 34 CRC); the right not to be subjected to torture or other cruel, inhuman, or degrading treatment or punishment, including corporal punishment (Arts. 37 (a) and 28, para. 2 CRC); measures to promote the physical and psychological recovery and social reintegration of child victims (Art. 39 CRC); and the availability of helplines for children. Under this cluster, States parties should take into account the Committee's General Comment No. 8 (2006) on the right of the child to protection from corporal punishment and other cruel or degrading forms of punishment, General Comment No. 13 (2011) on the right of the child to freedom from all forms of violence, and Joint General Recommendation No. 31 of the Committee on the Elimination of Discrimination against Women/General Comment No. 18 (2014) of the Committee on the Rights of the Child on harmful practices.

The cluster "Family Environment and Alternative Care" includes information on family preservation, where applicable, adoption and intercountry adoption, the alternative care system, the situation regarding children of imprisoned mothers, and the recovery of maintenance for children. Under this cluster, States parties should take into account the Committee's General Comment No. 7 (2005) on implementing child rights in early childhood and consider the Guidelines for the Alternative Care of Children (General Assembly resolution 64/142, annex).

The next cluster is "Disability, Basic Health, and Welfare." As regards disability, States parties should provide relevant and up-to-date information in respect of children with disabilities and measures taken to ensure their dignity, self-reliance, and active participation in the community, through access to all kinds of services, transportation and institutions, and, in particular, to education and cultural activities.

Implementation of basic health rights requires that attention be paid to survival and development and to health and health services, in particular, primary health care; the State party report must detail efforts to address the most prevalent health challenges to promoting the physical and mental health and well-being of children and to prevent and deal with communicable and noncommunicable diseases; it should reflect on reproductive health rights of adolescents and measures to promote a healthy lifestyle as well as measures to protect children from substance abuse.

The State party report should contain details regarding social security and childcare services and facilities and provide information on children's standard of living and measures taken, including material assistance and support programs with regard to nutrition, clothing, and housing, to ensure children's physical, mental, spiritual, moral, and social development and to reduce poverty and inequality. Relevant General Comments to be assimilated under this cluster include General Comment No. 3 (2003) on HIV/AIDS and the rights of the child, General Comment No. 4 (2003) on adolescent health and development in the context of the CRC, General Comment No. 9 (2006) on the rights of children with disabilities, and General Comment No. 15 (2013) on the right 
of the child to the enjoyment of the highest attainable standard of health (Art. 24), according to the Revised Guidelines (par 35-37).

Under the cluster "Education, Leisure, and Cultural Activities," information should be provided about the right to education, including vocational training and guidance, the aims of education with reference also to the quality of education and to education on human rights and civic education, the cultural rights of children belonging to indigenous and minority groups, and children's access to their rights to rest, play, leisure, recreation, and cultural and artistic activities. Under this cluster, States parties should take into account the Committee's General Comment No. 1 (2001) on the aims of education; General Comment No. 7 (2005) on implementing child rights in early childhood, General Comment No. 9 (2006) on the rights of children with disabilities, General Comment No. 11 (2009) on indigenous children and their rights under the Convention, and General Comment No. 17 (2013) on the right of the child to rest, leisure, play, recreational activities, cultural life, and the arts (Art. 31 CRC) (Revised Guidelines par 38-39).

The final cluster on "Special Protection Measures" requires information to be furnished on a wide range of vulnerable groups, including children in street situations, child labor, children who have been victims of sexual and other forms of exploitation, the juvenile justice system and the circumstances of children deprived of their liberty, children in armed conflict, and refugee and migrant children, to cite some groups. Under this cluster, States parties should take into account the CRC Committee's General Comment No. 6 (2005) on the treatment of unaccompanied and separated children outside their country of origin, General Comment No. 10 (2007) on children's rights in juvenile justice, and General Comment No. 11 (2009) on indigenous children and their rights under the Convention.

Pars 10 and 11 of the Revised Guidelines present the requirements for follow-up reports under the two mentioned Optional Protocols. An annex to the Revised Guidelines details the array of statistical information that should flesh out the State party report on the CRC and the follow-up reports on the two Optional Protocols.

\subsection{The Reporting Process}

\section{Compilation and Submission of the State Party Report and the Role of Civil Society}

The submission of a State party report to the CRC Committee triggers a fairly welldefined process. To consider State party reports (and conduct other business), the CRC Committee meets three times a year in Geneva for a period of 4 weeks. Three weeks are spent in plenary session with State party representatives, and 1 week is spent in presessional working group meetings with NGOs, UN Agencies, NHRIs, and children (http://www.ohchr.org/Documents/HRBodies/CRC/GuideNgoSubmission_ en.pdf (hereafter NGO Guide).

Note that if the State party has not submitted a report by the deadline given to it, the review by the CRC Committee will be delayed until the report is received. The Committee has thus far not scheduled a review in the absence of a submitted State 
party report. NGOs and NHRIs should not submit their reports on the deadline set for the State party but rather wait to see when the State party review is actually scheduled, in case the State party report is delayed.

Once the date for the formal presentation of a State party report has been established (often more than a year from the date of receipt of the State party report due to the heavy workload of the Committee), civil society is alerted to the possibility of submission of a complementary report or reports. The NGO Child Rights Connect, based in Geneva, plays an important role in advising civil society how to engage with the reporting process, and there are also clear guidelines for the format, structure, and length of civil society reports, which should not exceed 20,000 words (excluding annexes (NGO Guide $\mathrm{p}$ 14). In practice, civil society organizations are encouraged to form coalitions to prepare complementary reports, as this strengthens the weight of the submission. Be that as it may, there is nothing preventing civil society within a country or at the global level from submitting information generally or on a themed issue. One example is the international nongovernmental organization International Social Service (ISS) which often compiles fact sheets on a country's alternative care system for the Committee's consideration; another is the Global Initiative to End All Forms of Corporal Punishment of Children, which routinely submits country briefs. An analysis of the Concluding Observations (Cos) of the CRC Committee reveals that interest groups with targeted constituencies have successfully inserted their issue on the CRC Committee agenda from time to time. A recent example concerns the frequent reference to discrimination experienced by LGBTI children (see, e.g., $\mathrm{CRC} / \mathrm{C} / \mathrm{CMR} / \mathrm{CO} / 3-5$ Cameroon para 14) and gender normalization surgery of intersexed born children which is routinely performed in some countries (see, e.g., $\mathrm{CRC} / \mathrm{C} / \mathrm{ZAF} / \mathrm{CO} / 2$ South Africa para 39 and 40). These issues have really only surfaced in COs in the last couple of years, arguably due to the intervention of CSOs dedicated to the rights of LGBTI children.

\section{The Prehearing Session and the Participation of Children}

Once submitted, the civil society report is scheduled for consideration at the session held 6 months before the scheduled date for the hearing of the State party report (called the prehearing session). The report should be submitted 3 months before the scheduled presession, in English preferably. The deadline for the NHRI or a children's ombudsman's report is the same as for the NGO report. Civil society's delegation(s) are heard by the Committee in private, behind closed doors. Child Rights Connect liaises with NGOs and NHRIs to obtain permission to publish their reports on the website of the Committee and the Alternative Report Database, but if permission to publish is not given, these reports are kept confidential.

UNICEF field offices generally prepare a confidential written report for the Committee based on what they see as the priority children's rights issues in the State under review. At the presession, UNICEF representatives, if present, make a brief presentation and respond to the Committee's questions together with the NGO and NHRI representatives. They often attend the plenary session as observers as well and advise governments on the preparation of their State party report (NGO Guidelines p 17). 
The Committee has in recent times encouraged the participation of children in the prehearing sessions, too. In October 2014, the CRC Committee released a document outlining its working methods for the participation of children in the reporting process (hereafter Working Methods - Child Participation document). Reiterating the principles of the need for such participation to be "voluntary, respectful, relevant, in a child friendly environment, inclusive, supported by training, safe and sensitive to risk, and accountable" (par 7, drawing on General Comment No. 12), the Committee outlines the main ways in which children can be involved, namely, through children's submissions, either their own or through NGOs, for the adoption of lists of issues and review of States party reports, by means of oral presentations during the meetings of the presessional working groups, via private meetings with the Committee members during the meetings of the presessional working groups, by participating in videoconferencing, and by participation in plenary sessions of the Committee.

The Committee strongly encourages children to participate in the reporting process either by contributing to NGO reports or submitting their information through childled organizations and informal children's groups or NGOs and emphasizes that special measures to ensure that children in marginalized and vulnerable situations - such as girls, young children, children affected by poverty, children in street situations, children in institutions, children with disabilities, refugee and displaced children, children in conflict with the law, and children belonging to indigenous and minority groups - should be encouraged and enabled to participate in the reporting process on an equal basis with other children (Working Methods - Child Participation par 9).

While the presessional working group is more technical and less child-friendly than a children's meeting (see below for children's meeting), children have the opportunity to attend the working group meeting along with other nongovernmental stakeholders and to make presentations to the Committee. They can give their opinion on the State party report and highlight the key concerns and problems that children are facing in their country. Their input is confidential as presessional working groups are not open to the public (although UNICEF, NHRIs, and NGOs may be present) (Working Methods - Child Participation par 19).

Children's meetings are governed by par 23 of the Working Methods - Child Participation Guidelines. In addition to attending the presessional working group meeting, children's groups or organizations may request a private meeting with the Committee or country rapporteurs during the meeting of the presessional working group (this is the "children's meeting"). The private meeting allows children to have informal interactions with the Committee members. The children's meeting is exclusively for children who are under the age of 18 at the time of the meeting and lasts $1 \mathrm{~h}$. The children's meeting has a more child-friendly format and setting than the presessional meeting. While there is no formal structure for these meetings, they usually consist of children presenting the key issues and recommendations either orally or through a video, with time being allotted for Committee members to ask the children questions. According to par 27 of the Working Methods - Child Participation Guidelines, accompanying adults should focus on supporting the children and refrain from giving their own opinions or trying to influence the opinions of the children. They should also ensure that children are able to communicate and participate in discussions outside the children's meeting. 


\section{The Interactive Hearing: Constructive Dialogue}

At the conclusion of the prehearing session, the Committee compiles a list of issues (LOI) to be addressed by the respective State party prior to the formal presentation of the State party report (usually 6 months after the CRC presessional working group). The LOI is intended to give the Government a preliminary indication of the issues which the Committee considers to be priorities for discussion (Working Methods document 2014). The LOI will typically require the State party to provide any additional information and updates on developments that have occurred since the submission of the State party report (such as new legislation that has been passed), ask for more information about specific themes raised in the periodic report or by the civil society delegation, and request updated data that the Committee is desirous of receiving. The government's written response to the LOI, as indeed the LOI itself, are public documents and available on the treaty body database. Civil society reports are to be found there, too, where permission has been granted for public dissemination or at least where civil society has not requested that its report be kept under wraps. Civil society reports that are available are captured only in the language in which they were submitted, and the UN system does not translate them for a wider audience.

When presenting a State party report to the Committee, delegations are given an opportunity to make a presentation, after which Committee members can pose questions. Each State party report is allocated precisely the same amount of time, irrespective of the population size or geographical reach of a country. By way of example, in 2014 in its consideration of the State party report of the Kingdom of the Netherlands, the review included not just the situation in the Netherlands itself but also all of the overseas territories falling under the Kingdom, such as St. Martin and Curacao.

The nature of the interactions between the Committee and government delegations has been characterized as a "constructive dialogue" (OHCHR Guidance note on Constructive Dialogue A/69/285). This characterization provides an indication of the nature of the process: it is meant to be one of dialogue, not of adjudication in the sense of court proceedings. Primarily, the task of the treaty bodies is to convince and persuade rather than to judge. The constructive dialogue presents an opportunity for the State party to receive expert advice on their compliance with their international treaty obligations. The CRC Committee will appoint in advance a country rapporteur (or in the case of large countries, or those with a large number of NGO reports, a task force consisting of four or five members) who will familiarize him or herself (or themselves) most closely with the State party to be reviewed and whose task during the constructive dialogue is to act as the focal point for introducing and coordinating the dialogue (OHCHR Guidance note on Constructive Dialogue A/69/ $285 \mathrm{p} 1$ ). Supplementary questions may be posed by any treaty body member as necessary. However, increasingly the focus of at least initial questioning is the appointed rapporteurs or task force. Treaty body members who are nationals of the State party under review, or for whom there is another potential conflict of interest, do not participate in the entire process, including the constructive dialogue and the formulation of the COs.

The constructive dialogue takes place in two meetings of $3 \mathrm{~h}$, normally spread over 2 days (so that the representatives of the State party have time to find answers to 
questions posed that they might not necessarily readily know offhand). The focus of the dialogue in relation to periodic reports are thematic priorities identified by the Committee, previous concluding observations, challenges identified in the LOI, and possible new developments in the State party to which the Committee's attention has been drawn (OHCHR Guidance note on Constructive Dialogue A/69/285 p2.) Questions posed by the Committee will usually be clustered by themes (along the lines of the Revised Guidelines, as above). Time allocations are strictly controlled (e.g., the opening statement of the State Party is limited to 15-30 min) with a view to maximizing the time for direct exchange between the Committee members and representatives of the State party. The constructive dialogue is held in a public meeting, which may be attended by any observer provided advance accreditation is obtained (although observers may not participate directly). According to the Committee's (general) working methods document:

[w]ith the factual situation largely clarified in writing, there should be room in the discussions to analyse "progress achieved" and "factors and difficulties encountered" in the implementation of the Convention. As the purpose of the whole process is constructive, sufficient time should be given to discussions about "implementation priorities" and "future goals". For these reasons the Committee welcomes the representation of the State party to be a delegation with concrete involvement in strategic decisions relating to the rights of the child. When delegations are headed by someone with governmental responsibility, the discussions are likely to be more fruitful and have more impact on policy-making and implementation activities. (Working Methods part II B)

At the end of the session at which the report has been presented, the Committee will issue Concluding Observations (COs) for all of the reports dealt with during that period. The COs follow a standard format which in substance mirrors the clustering of rights suggested in the Reporting Guidelines. This is preceded by a section outlining positive measures of implementation which the Committee commends the respective government for adopting or having achieved. Having dealt with its concerns in relation to substantive CRC rights in the mentioned thematic clusters, in conclusion the last paragraphs identify other human rights treaties that the State party is encouraged to ratify, African signatories are encouraged to cooperate with the African Committee of Experts on the Rights and Welfare of the Child, and follow-up and dissemination of the COs in the State party are covered.

COs are prepared in first draft by the Secretariat at the Office of the United Nations High Commissioner for Human Rights (OHCHR), together with the designated country rapporteur(s). Final approval after inputs from other Committee members takes place at a private Committee meeting (Sahovic et al. 2013: 347). The COs are made public on the last day of a Committee session during the adoption of the session report, of which they form a part. Once adopted, they are made available to the States parties concerned and also issued as official documents of the Committee. The United Nations General Assembly has placed a word limit on all treaty bodies' documentation, including COs, which may not exceed a limit of 10,700 words for each document produced by the respective human rights treaty 
bodies (GA A/Res/68/268 of 21 April 2014 par 15). It has been said that the ultimate goal is to reduce this further to 6000 words (Private Communication from a CRC Committee member, June 2017). This has obvious implications for the level of detail, quality, and possibly clarity of the COs. Since 2016, in accordance with guidance to treaty bodies generally, the CRC Committee has identified around six priority recommendations in the $\mathrm{CO}$ that States parties are urged to attend to, alongside the other concerns spelt out. These priority concerns, drawn from the body of recommendations, are clearly identified in an initial section of the COs titled "Main concerns and recommendations."

In accordance with Article 44, paragraph 5, of the Convention, the Committee's reports are submitted to the United Nations General Assembly, through the Economic and Social Council, for its consideration, every 2 years. The most recent report was submitted on 27 September 2016 (A/71/150).

\section{Toward a More Targeted Reporting Process?}

The Human Rights Committee adopted a new optional reporting procedure from 2013, the so-called (LOIPR)/Simplified Reporting Procedure. At its ninety-seventh session, held in October 2009, the Committee started discussing its draft revised reporting guidelines. In this context, it decided to adopt a new reporting procedure whereby it would send States parties a list of issues (a so-called list of issues prior to reporting (LOIPR)) and consider their written replies in lieu of a periodic report (a so-called focused report based on replies to a list of issues). Under the new procedure, the State party's answer would constitute the report for the purposes of Article 40 of the Covenant. Guidelines are to be found at CCPR/C/99/4. The procedure was also adopted by the Committee on the Right of Persons with Disabilities for periodic reports which were due in 2014 and beyond. According to this procedure, the Committee also prepares and adopts lists of issues to be transmitted to States parties, and the replies of the State party to this list of issues are deemed to constitute the State party report. This procedure aims to facilitate the States parties reporting process, strengthen the States parties capacity to fulfil their obligations in a timely and effective manner, provide the Committee with more targeted periodic reports, improve the effectiveness of the treaty monitoring system by reducing the need to request supplementary information before considering a report, and allow the Committee to plan in advance its work.

Although the CRC Committee has not yet adopted this procedure, it is being discussed for the future.

\subsection{Assessment of the Monitoring Function of the CRC Committee Through the Reporting Process}

Some commentators give an overall positive assessment of the role of the CRC Committee. Commenting on the twenty-fifth anniversary of the adoption of the CRC, Karin Arts concludes that "through the years the CRC Committee, mandated to monitor and facilitate compliance with the Convention, has contributed to the 
realization of various improvements of the CRC treaty regime, which were both substantive and procedural in nature. The Committee has certainly developed into an active and vocal actor for children's rights in the world. Research has revealed that the CRC Committee followed its own course fairly independently, rather than always following ongoing trends and hypes" (Arts 2014: 291). She notes, though, that "the monitoring work done by the UN Committee on the Rights of the Child can also only be done well if the Committee itself is properly resourced.... this aspect too has been problematic since the early days of the Convention" (Arts 2014: 304). Lack of resources may affect the staffing available to the Committee, printing of documents, field trips, translation, and all manner of supportive activities.

Also in a positive vein, Sahovic et al. 2013: 342 point out, "[e]xamination of the progress made by States parties is a multi-layered and dynamic process." They also refer in a positive vein to the lengthy process of State party reporting, noting that it takes place in the context of (usually) extended preparation at the national level, often involving many ministries and agencies, as well as NGOs and children themselves. For the most part, they conclude that States party reports have steadily improved in quality and that the amount of information available to the Committee through UN agencies, and domestic and international NGOs, has grown too.

As regards the quality of NGO complementary reports, with the guiding hand of the NGO Group for the Convention on the Rights of the Child (now Child Rights Connect, a network of 79 international and national NGOs which developed from the NGO collation that supported the drafting of the CRC), the then program officer was able to demonstrate persuasively in 2007 how the quality of these reports had improved exponentially since the first ones were submitted in the early-mid 1990s (Theytaz Berman 2007). Sahovic et al. (2013: 350) also share this view, referring both to the structure of the NGO reports and to their capacity to "evaluate the situation for children in their countries and to eloquently present it to the CRC Committee." Nevertheless, the sheer volume of available information is at the same time a burden to the Committee, which drowns in reports, submissions, summaries, and background briefings. This may make it difficult to "see the wood for the trees."

Treaty bodies do not have judicial powers. Therefore, it is clear that COs, per se, impose no legal obligation on State parties (O'Flaherty 2006). As Sahovic et al. opine (2013: 364), "[t]he concluding observations may be seen as an agenda for action, but there is no formal mechanism to ensure that the recommendations made by the CRC Committee are actually implemented. The implementation depends on the measures the government is willing to take, the priorities within the policies and programmes of the country, and the allocation of adequate human and financial resources." Furthermore, they note that the CRC Committee has not established a robust follow-up procedure other than the requirement that States parties must inform the CRC Committee in the following reporting cycle of the measures taken to implement the recommendations contained in the COs. This gap is explained by these authors by the fact that the Committee is overloaded with reviewing reports on the CRC and its two Optional Protocols. 
Although the COs can be regarded as constituting a form of "soft law," it has been noted that "[u]nfortunately, given the relatively short time that the treaty bodies can dedicate to each country, the concluding observations remain often at a rather general level, and their jurisprudential impact is marginal and exceptional" (Mechlem 2009: 922). It has also been noted that due to the 5-year gap between periodic reports (those which are submitted timeously - late reporting and combined periodic reports has been fairly endemic in the history of CRC reporting by State parties), means that review of State parties are rather infrequent (Heyman and McNeill 2014)

Polonko et al. (2016: 29) point to the enormous difficulty in practice of comparing data derived from States reports and COs across countries due to a lack of consistency in reporting and the complexity of information provided. The few researchers that have devoted attention to the general (as opposed to country-specific) nature of the CRC Committee's COs (such as Stein and Spronk) have had the following observations to make.

Stein (2016) points to a continuous improvement in the formulation of the COs, based on her study of 419 COs related to child statelessness. Spronk (2014) alludes to similarly formulated COs for countries which vary enormously as regards development, in the context of the right to the highest attainable standard of health, suggesting a somewhat formulaic development of COs. A similar comment was made by the present author ("many comments, suggestions, recommendations and observations are similar or identical" - noting that this limits the ability of researchers to differentiate between countries (Sloth-Nielsen 2015: 3). The point is further made that "concluding observations are not necessarily sufficiently detailed to enable conclusions to be drawn about the actual effectiveness, or the comparability of different implementation mechanisms: all too often reference made (in a positive vein) to the existence of one body or another, or (in a negative vein) to its absence, or the need for it to be strengthened." The conclusion drawn is that intercountry comparisons which point to "good" or "best" practice or even "models of excellence" are therefore harder to extract (Sloth-Nielsen 2015: 7).

Krommendijk's recent study selected the Netherlands, New Zealand, and Finland, all strong liberal democracies, for examination of the impact of treaty bodies COs, because they were considered most likely cases for the effectiveness of international monitoring in the field of human rights. He found (encouragingly) that most of the legislative, policy, or other measures that were taken (partly) as a result of COs of the various UN treaty bodies were related to the COs of the CRC Committee; his research shows that 33 of the 74 responses related to the COs from the CRC Committee (Krommendijk 2014: 374) (compared for instance to only four COs emanating from the ICCPR). Although COs are not binding, Krommendijk (2015) argues that one crucial precondition for the effectiveness of what are termed "reputational models" of accountability is that the target State and the wider domestic and international audience bestow reputation on the treaty bodies and consider them as important and legitimate. The possible reputational costs for States for not acting upon COs are low if a treaty body is not considered legitimate and does not have a solid reputation. However, his study did not show that the effectiveness of COs of 
the CRC Committee was linked to an enhanced reputational legitimacy of the CRC Committee: "Government officials [interviewed] were, however, not more positive about the CRC Committee and its COs, compared with the other treaty bodies. They were sometimes even more critical about the CRC Committee" (Krommendijk 2014: 377-378). He concludes that "[1] egitimacy-based explanations can thus not account for the higher effectiveness of the COs of the CRC Committee" (Krommendijk 2015: 503). Krommendijk proceeds to hypothesize that the effectiveness of the CRC Committee's COs can primarily be explained by the mobilization and lobbying of domestic actors. His data proves the validity of this hypothesis in relation to CRC Committee's COs concerning juvenile detention in the Netherlands, the abolition of corporal punishment in New Zealand, and the recommendation of the CRC Committee to Finland to establish a separate Children's Ombudsman. The CRC and the COs were also considered useful instruments for domestic pressure groups and advocates to hang their arguments on and gave them a strong position upon which to discuss and base advocacy efforts (Krommendijk 2015: 505). He does note that there had been more mobilization and lobbying from domestic actors in relation to the CRC Committee than the other treaty bodies, as well as more media attention paid to the CRC Committee reporting process. He concludes nevertheless that "COs have had an intensifying or catalyst effect, whereby they supported, strengthened or legitimized the arguments of domestic actors. COs have in this way supported or given extra strength to a certain direction and have pushed or accelerated a certain political process" (Krommendijk 2015: 506). Simmons, too, concludes that the limited evidence available so far indicates that the CRC has had more effects than other treaties in some countries (2009: 357).

Finally, it has been lamented that the UN system limits the length of COs (Doek, 2016, "personal communication"). While levelling the playing fields as regards individual States parties so as to ensure that no State party gets more time for dialogue than another, nor that one State party receives more extended or comprehensive recommendations from the CRC Committee than others, it is nevertheless difficult to reconcile a "one-size-fits-all approach" with contexts as diverse as China (with 302 million children at 2012 figures https://www.unicef.org/infobycountry/ china_statistics.html) and Vanuatu (with a child population of approximately 110,000 at 2012 figures (https://www.unicef.org/infobycountry/vanuatu_statistics. $\mathrm{htm})$. Also, in an effort to clear the backlog of reports occasioned by the widespread ratification of the treaty, the CRC Committee increased the number of reports to be considered at each session from six to nine, which meant a reduction in time per report from $9 \mathrm{~h}$ to 6 , which is much less time for detailed discussion (Sahovic et al. 2013: 361). However, this concern applies to other treaty bodies as well, since the $6 \mathrm{~h}$ devoted to the constructive dialogue on State reports has been introduced for all of them.

It has been suggested by some commentators that sometimes the Committee "gets it wrong," focussing on issues which are not in practice that serious or concerning or not accepted by the State party. For instance, the Committee's reaction to the possibility of child euthanasia in the Netherlands was adversely received in the country. Similarly, the criticism of South Africa's overcrowded detention facilities 
seems out of place given the $1000 \%$ reduction in children deprived of their liberty in prisons in the preceding 5-year period (Sloth-Nielsen 2017b). Some analysts perceive that the Committee has paid too little attention to civil and political rights, although this can be disputed, given the attention to such issues as birth registration and violence against children and their protection from all forms of cruel and inhuman treatment or punishment that the Committee has paid. As mentioned, the COs can be seen being in an ongoing state of development, with recent COs devoting space to climate change, growing child obesity, and implementation of the Sustainable Development Goals (SDGs). It is beyond the scope of this chapter, however, to engage in a full analysis of the Committee's COs.

\title{
3 Implementation Provisions of the CRC
}

\subsection{Definition and Legal Basis}

Implementation is the process whereby States parties take action to ensure the realization of all rights in the Convention for all children in their jurisdiction (CRC/GC/5 2003 par 1). The starting point for the consideration of the implementation obligation at domestic level is, in general, governed by Article 4 of the CRC which reads as follows:

\begin{abstract}
States Parties shall undertake all appropriate legislative, administrative, and other measures for the implementation of the rights recognized in the present Convention. With regard to economic, social and cultural rights, States Parties shall undertake such measures to the maximum extent of their available resources and, where needed, within the framework of international cooperation.
\end{abstract}

Other general implementation obligations are set out in Article 2 CRC: "States Parties shall respect and ensure the rights set forth in the present Convention to each child within their jurisdiction without discrimination of any kind ..."; also under Article 3, paragraph $2 \mathrm{CRC}$, "States Parties undertake to ensure the child such protection and care as is necessary for his or her well-being, taking into account the rights and duties of his or her parents, legal guardians, or other individuals legally responsible for him or her, and, to this end, shall take all appropriate legislative and administrative measures." (CRC/GC/5 2003 par 3 and 4).

The ACRWC implementation provisions are not couched in the same terms, as Article 1 (1) of this treaty provides that:

member states shall recognise the rights, freedoms and duties enshrined in this Charter, and shall undertake the necessary steps, in accordance with their constitutional processes and with the provisions of the present Charter, to adopt such legislative or other measures as may be necessary to give effect to the provisions of this Charter.

Hence, this provision does not explicitly mention administrative measures nor does it expressly allude to progressive realization of social, economic, and cultural 
rights, using available resources to the maximum extent. However, it is generally accepted that the implementation standard of the two treaties is similar. According to the Handbook on the ACRWC:

as the emerging jurisprudence of this Committee shows, the Committee believes that economic social and cultural rights should be justiciable in the same way as are civil and political rights. Moreover, whatever their economic circumstances, States are required to undertake all possible measures towards the realization of the rights of the child, paying special attention to the most disadvantaged groups. This necessarily implies progressive realization. The Committee is, of course, fully aware that social spending in State parties in African context oftentimes proceeds off a low base, but argues the Charter standards were set intentionally - they do not allow states to claim that they do not have any resources for the implementation of social and economic goods for the fulfilment of children's rights. State parties, whatever their economic resource base, have been urged to comply with agreed targets relating to social spending, and to include such information in their State party reports. It is further noted that the fulfilment of civil and political rights can also require extensive resource allocation, such as improving birth registration systems. This, too, explains why no priority is accorded the development of either civil and political, or social, economic and cultural rights, in the text of Article 1. (Handbook on the Implementation of the ACRWC, forthcoming)

The lack of reference to progressive realization of social, economic, and cultural rights in the Charter will warrant further elaboration when the African Committee of Experts on the Rights and Welfare of the Child adopts an envisaged General Comment on General Measures of Implementation of the African Charter on the Rights and Welfare of the Child and Systems Strengthening in 2017 or 2018.

\subsection{Specific Areas of General Implementation}

GC 5 (General Measures of Implementation of the Convention on the Rights of the Child) provides the starting point which teases out the implications of Article 4 in more concrete form. In particular, GC 5 highlights more than ten very specific areas of general implementation. First, as a general measure of implementation, the Committee invites State parties to indicate whether they consider it necessary to maintain any reservations they have made, if any, or have the intention of withdrawing them, because "full and unqualified respect for the human rights of children can be achieved only if States withdraw their reservations" (CRC/GC/5 2003 par 13). Ratification of other relevant international human rights instruments is regarded as a second implementation imperative (CRC/GC/5 2003 par 17). A comprehensive review of all domestic legislation and related administrative guidance to ensure full compliance with the Convention is a further obligation. The review needs to be continuous rather than one-off, reviewing proposed as well as existing legislation (CRC/GC/2003/5 2003 par 18).

Additionally, third, States parties need to ensure, by all appropriate means, that the provisions of the Convention are given legal effect within their domestic legal systems. Even in States where the provisions of ratified treaties are so-called self- 
executing, this may be problematic, because the standard required is that of incorporation into domestic law, which in turn should mean "that the provisions of the Convention can be directly invoked before the courts and applied by national authorities and that the Convention will prevail where there is a conflict with domestic legislation or common practice" (CRC/GC/5 2003 par 19). The GC notes, in particular, the importance of ensuring that domestic law reflects the identified general principles in the Convention (Arts. 2, 3, 6, and 12) and welcomes the development of consolidated children's rights statutes, which can highlight and emphasize the Convention's principles (CRC/GC/5 2003 par 22). Because children's special and dependent status creates real difficulties for them in pursuing remedies for breaches of their rights, States need to give particular attention to ensuring that there are effective, child-sensitive procedures available to children and their representatives to pursue breaches of rights and to ensure justiciability of all rights, including social, economic, and cultural rights (CRC/GC/5 2003 par 24).

Fourth, under the rubric "Administrative and Other Measures," GC 5 alludes to the necessity of cross-sectoral coordination to recognize and realize children's rights across Government, between different levels of government and between Government and civil society - including, in particular, children and young people themselves (CRC/GC/5 2003 par 27). It further commends the development of a comprehensive national strategy or national plan of action (NPA) for children, built on the framework of the Convention. This plan should be developed through a consultative process, taking into account the previous recommendations contained in COs emanating from periodic reports (CRC/GC/5 2003 par 29). The NPA should pay particular attention to identifying and giving priority to marginalized and disadvantaged groups of children. Further, the NPA should be endorsed at the highest level of government. The strategy will need to include arrangements for monitoring and continuous review, for regular updating and for periodic reports to Parliament and to the public (par 31 and 33). The existence of a national coordinating machinery is also important to make children more visible in Government, according to Rishmawi (2006: 51).

Fifth, the GC continues to highlight the necessity of effective coordination among central government departments, among different provinces and regions, between central and other levels of government and between Government and civil society, for the implementation of CRC rights. Detailed arrangements appropriate for very different systems of government across States parties cannot be prescribed, as there are many formal and informal ways of achieving effective coordination, including (e.g.) interministerial and interdepartmental committees for children. Although it is not practicable to bring responsibility for all children's services together into a single department, the GC recommends that a special unit, given high-level authority reporting directly, for example, to the Prime Minister, the President, or a Cabinet Committee on children - can contribute both to the overall purpose of making children more visible in Government and to coordination to ensure respect for children's rights across Government and at all levels of Government (par 39). In 2016, the OHCHR released a practical guide to national reporting and follow-up mechanisms, advocating for national mechanisms for reporting and follow-up. 
These, in the view of the OHCRC, have the potential to become one of the key components of the national human rights protection system, bringing international and regional human rights norms and practices directly to the national level.

The essence of the reporting process is nationally driven. National mechanisms for reporting and follow-up build national ownership and empower line ministries, enhance human rights expertise in a sustainable manner, stimulate national dialogue, facilitate communication within the Government, and allow for structured and formalized contacts with parliament, the judiciary, national human rights institutions and civil society. (Preamble)

A national mechanism for reporting and follow-up is a national public mechanism or structure that is mandated to coordinate and prepare reports and engage with international and regional human rights mechanisms (including treaty bodies, the universal periodic review, and special procedures) and to coordinate and track national follow-up and implementation of the treaty obligations and the recommendations emanating from these mechanisms. It may be ministerial (e.g., within the Ministry of Foreign Affairs), interministerial, or institutionally separate. As a governmental structure, it has a permanent life beyond an individual report to a single treaty body.

According to the OHCHR, the following benefits of a national reporting and follow-up mechanisms can be adduced in that it:

- "Establishes a national coordination structure, thereby creating national ownership of reporting and follow-up and regular interaction within ministries and with ministries engaging seriously in reporting and follow-up;

- Makes communication between ministries easier and more direct, thereby creating efficiencies and maximizing resource

- Systematizes and rationalizes the engagement with international and regional human rights mechanisms, including the preparation of reports, and coordinates follow-up, thereby ensuring national coherence;

- Empowers ministerial focal points to communicate and explain the human rights system and its recommendations within their ministries, thereby actively contributing to the development of policies and practices;

- Allows for structured and formalized contacts with parliament, the judiciary, NHRI and civil society, thereby mainstreaming human rights at the national level, strengthening public discourse on human rights, and improving transparency and accountability; and

- Builds professional human rights expertise in every State." (OHCHR, National Reporting and Follow Up mechanisms p4-5)

The CRC Committee treaty body has expressed serious concern where a coordinating mechanism does not exist. In relation to Madagascar, for instance, the Committee noted in 2012 with concern that: 
there is no single government entity responsible for overall coordination of the policies, laws and programmes relating to children's rights. The Committee notes that the Ministry of Population and Social Affairs plays a role in coordinating and monitoring children's rights and that specific sectoral coordination forums exist. However, the Committee notes with concern that these mechanisms are inadequate to ensure an effective and comprehensive coordination of implementation of children's rights across all sectors and between national and regional levels. (CRC/C/MDG/CO/3-4 Madagascar 2012 par 10)

The coordinating mechanism needs to have authority at a high enough level in government (as a whole). It must have effective access to decision-making structures of government and have the capacity to hold line ministries or departments to account and to enforce its decisions and requirements. In short, it must be sufficiently authoritative and placed at such a level in the hierarchy of government, as to be "effective" (a word stressed by the CRC Committee).

A common development has been the inauguration of child rights councils, which tend to be semiautonomous bodies established to perform certain child rights-related functions. They cannot be seen as wholly autonomous because they are established and funded mainly by the government to carry out specific functions under a framework that requires close collaboration with the executive branch of government. The most notable advantage that child rights councils have over the ministerial coordinating bodies lies in the fact that they are established specifically to exercise interdepartmental or interministerial coordination functions. In some cases, such coordination powers extend to the private sector, and NGO delegates may enjoy formal representation on the council (Chirwa 2015: 27). Although the functions and mandates of child rights councils differ considerably, common functions relate to inter-sectoral coordination, policy-making, planning, advice giving, advocacy for children's rights, training, direct service delivery to children, and awareness raising about children's rights and children's issues. A particular challenge, however, has been the lack of financial and human resources afforded to these councils, as noted by the CRC Committee from time to time (see, e.g., the COs of the CRC Committee in relation to Sudan CRC/C/SDN/CO/3-4 22 October 2010).

Sixth, GC 5 deals with decentralization, federalization, and delegation of functions to lower tiers, none of which reduce the direct obligations of State parties' governments to fulfil their obligations to all children within their jurisdiction. In any process of devolution, States parties have to make sure that the devolved authorities do have the necessary financial, human, and other resources effectively to discharge responsibilities for the implementation of the Convention (par 40). "The Governments of States parties must retain powers to require full compliance with the Convention by devolved administrations or local authorities and must establish permanent monitoring mechanisms to ensure that the Convention is respected and applied for all children within its jurisdiction without discrimination. Further, there must be safeguards to ensure that decentralization or devolution does not lead to discrimination in the enjoyment of rights by children in different regions" (CRC/GC/ 52003 par 40).

Next GC 5 deals with privatization; however, the remarks have since been supplemented by GC 16 (children's rights and the business sector), which is not 
discussed in this chapter. Proceeding to the seventh theme, the GC at par 45 highlights that " $[\mathrm{e}]$ nsuring that the best interests of the child are a primary consideration in all actions concerning children (art. 3 (1)), and that all the provisions of the Convention are respected in legislation and policy development and delivery at all levels of government demands a continuous process of child impact assessment (predicting the impact of any proposed law, policy or budgetary allocation which affects children and the enjoyment of their rights) and child impact evaluation (evaluating the actual impact of implementation)." This has been further elaborated in General Comment No. 19 (2016) on children's rights and public spending, discussed briefly below.

Eighth, the GC turns to data collection and analysis and the development of indicators. "Collection of sufficient and reliable data on children, disaggregated to enable identification of discrimination and/or disparities in the realization of rights, is an essential part of implementation" (CRC/GC/5 2003 par 48). Data collection needs to extend over the whole period of childhood, up to the age of 18 years. It also needs to be coordinated throughout the jurisdiction, ensuring nationally applicable indicators. It is insufficient to simply establish effective systems for data collection - the data collected must be evaluated and used to assess progress in implementation, to identify problems, and to inform all policy development for children.

Ninth, under the title "Making Children Visible in Budgets," the GC provides an initial discussion of the requirement of disaggregated budgets in which the proportion of spending on children can be properly identified and monitored - an issue taken up again in GC 19 discussed briefly below.

Tenth, the implementation mandate includes States' obligation to develop training and capacity-building for all those involved in the implementation process government officials, parliamentarians, and members of the judiciary, as well as for all those working with and for children, such as community and religious leaders, teachers, social workers, and other professionals. "The purpose of training is to emphasize the status of the child as a holder of human rights, to increase knowledge and understanding of the Convention and to encourage active respect for all its provisions" (CRC/GC/5 2003 par 53). Training needs to be systematic and ongoing and should be regularly reviewed for effectiveness and impact.

Eleventh is the issue of cooperation with civil society. While implementation is primarily the responsibility of State parties, the duty to respect and ensure the rights of children extends in practice beyond the State and State-controlled services and institutions to include children, parents and wider families, other adults, and non-State services and organizations. Hence, the State needs to work closely with NGOs in the widest sense while respecting their autonomy (CRC/GC/5 2003 par 58). Governments are urged in GC 5 to give NGOs and NGO alliances and coalitions nondirective support and to develop positive formal as well as informal relationships with them.

The twelfth theme relates to international cooperation, since Article 4 emphasizes that implementation of the Convention is a cooperative exercise. The GC stresses that "the Convention should form the framework for international development assistance related directly or indirectly to children and that programmes of donor 
States should be rights-based" (CRC/GC/5 2003 par 61). On the part of international aid-receiving States, these States parties must allocate a substantive part of that aid specifically to children and be able to identify on a yearly basis the amount and proportion of international support earmarked for the implementation of children's rights $(\mathrm{CRC} / \mathrm{GC} / 52003$ par 61).

The final sections of the GC are devoted to the establishment and resourcing of independent human rights institutions, which enjoys a separate section below, to making the contents of the Convention widely known (Article 42 CRC) and to dissemination of periodic reports and COs within the domestic system (Article 46 CRC).

Implementation and budgeting for children have recently been supplemented by the adoption, on 20 July 2016 by the CRC Committee, of GC 19 on public budgeting for the realization of children's rights (Article 4). The GC elaborates on the principles of effectiveness (constantly assessing their budget decisions to ensure the best possible outcomes for children, $\mathrm{CRC} / \mathrm{C} / \mathrm{GC} / 192016$ par 59), efficiency (managing public resources and programs in such a way as to ensure value for money and bearing in mind the obligation to respect, protect, and fulfil children's rights, $\mathrm{CRC} / \mathrm{C} /$ GC/19 2016 par 69), equity (implementing the principle of nondiscrimination through resource mobilization and the allocation or execution of public spending, CRC/C/GC/19 2016 par 61), transparency (developing and maintaining public finance systems that are open to scrutiny which in turn combat corruption and maladministration, $\mathrm{CRC} / \mathrm{C} / \mathrm{GC} / 192016$ par 62), and sustainability (taking into account the best interests of current and future generations of children in budget decisions, $\mathrm{CRC} / \mathrm{C} / \mathrm{GC} / 192016$ par 63). States parties should not allow the existing level of enjoyment of children's rights to deteriorate, and retrogressive measures in times of economic crisis are permissible only after assessing all other options and ensuring that children are the last to be affected, especially children in vulnerable situations. "States parties shall demonstrate that such measures are necessary, reasonable, proportionate, non-discriminatory and temporary and that any rights thus affected will be restored as soon as possible" (CRC/C/GC/19 2016 par 31).

The GC also deals with implementation of the rights of the child in public budgets. Four stages are envisaged, namely, planning and the constituent steps needed to make this based on realistic information and the mobilization of resources (CRC/C/GC/19 2016 paras 67-86), enacting of budget proposals by legislatures at national and subnational levels (CRC/C/GC/19 2016 paras 87-93), executing (which includes monitoring revenue collection and tracking progress as set out in the budget in accordance with internal control and audit processes $(\mathrm{CRC} / \mathrm{C} / \mathrm{GC} / 19$ 2016 paras 94-103), and follow-up (which includes year-end reporting, evaluations, and rigorously assessing and considering the findings of such evaluations $(\mathrm{CRC} / \mathrm{C} /$ $\mathrm{GC} / 192016$ paras 104-111). The importance of independent auditing institutions is highlighted (CRC/C/GC/19 2016 par 108).

This GC is of use both to State parties and civil society as child rights budgeting is often seen as a specialized area, which few NGOs feel equipped to tackle. By spelling out some key "ground rules" for public finance management, particularly the fulfilment of children's socioeconomic rights (to the maximum extent of available resources) can be advanced. 


\subsection{Assessment of the Implementation of the CRC and the Rights it Provides For}

It is widely held that the signal achievement of the CRC has been in the sphere of law reform, with many countries having enacted constitutional rights for children, adopted comprehensive child protection and welfare laws which are more consistent with the rights-based approach of the $\mathrm{CRC}$, and updated or reformed sectoral laws such as in relation to health, education, trafficking, and disability (Lundy et al. 2013; Arts 2014; UNICEF IRC 2007; Van den Hole 2014). Yet as can be seen from the array of measures required by GC 5 for implementation, law reform is but one step in the complex process of implementation. No country, state, or entity can claim to have fully implemented the CRC, and no State party reports are going to be presented without the CRC Committee making recommendations for improvements. Thus, when the Holy See presented its report in 2013 (on children's rights in the Vatican), the CRC Committee engaged extensively and very publically with the delegation on the responses of the Catholic Church to investigating and ending child abuse by members of its clergy, not only in the Vatican but elsewhere in the world as well.

However, Van den Hole (Routledge 2014: 38) points out that a common starting point of scholars and practitioners is the so-called implementation gap approach: that this is the main challenge for children's rights, on the assumption that the legal standards, norms, and principles are clear, appropriate, and beyond doubt. Therefore the only remaining issue is how to enforce them. Many would agree, however, that although much remains to be done at the level of domestic enforcement, implementation requires ongoing norm setting and clarification, as new issues take center stage and fresh insights into child development, the dynamics of social change, and an array of other factors emerge to stretch the frontiers of children's rights. Implementation can therefore never be "finished business."

Second, as GC 5 points out, the CRC has indeed led to the "the development at the national level of a wide variety of new child-focused and child-sensitive bodies, structures and activities - children's rights units at the heart of Government, ministers for children, inter-ministerial committees on children, parliamentary committees, child impact analysis, children's budgets and 'state of children's rights' reports, NGO coalitions on children's rights, children's ombudspersons, and children's rights commissioners and so on.... While some of these developments may seem largely cosmetic, their emergence at the least indicates a change in the perception of the child's place in society, a willingness to give higher political priority to children and an increasing sensitivity to the impact of governance on children and their human rights" (CRC/GC/5 2003 paras 9 and 10).

Arts is of the view that a major obstacle to the implementation of children's rights is poverty (2014: 297) which has a structural basis. Another identified hurdle is the pervasive violation of children's bodily and psychological integrity through violence in its many manifestations, often culturally sanctioned. Therefore, hopes can be pinned on the fulfilment of the sustainable development goals (SDGs), which provide clear targets for both the elimination of extreme poverty but also other 
relevant indicators relating to development which uphold children's rights, such as education. And, as ending violence against children is an ongoing target of intervention under the SDGs, there is some expectation of progress on this front, too, in the implementation of children's rights.

\section{Monitoring of Children's Rights Implementation via Other Mechanisms}

It is beyond the scope of this chapter to detail fully the contribution of all treaty bodies, special mandate holders, and UN work toward the fulfilment of children's rights. However, it must be pointed out that children's rights is not - nor can it ever be - only the preserve of the CRC Committee at the global level and that significant contributions are made on many other domains (such as the CEDAW Committee in relation to issues impacting the girl child and the Convention on the Rights of Persons with Disabilities in relation to children with disabilities). Indeed, a fuller appraisal of children's rights across the entire UN system would be a welcome addition to the literature. However, the section below focuses selectively on special mandate holders specific to children's rights, on the monitoring mechanism established to combat child soldiers, and on the more political UPR process, in which children's rights frequently feature prominently.

\subsection{Special Mandate Holders and Monitoring of the Use of Child Soldiers at UN Security Council Level}

Article 45(c) of the CRC states that the CRC Committee may recommend to the General Assembly to request the Secretary General to examine specific issues relating to the right of the child. The Committee does not have the mandate to undertake investigations or studies itself (although the African Committee of Experts on the Rights and Welfare of the Child is endowed with this mandate and has exercised it increasingly in recent times, inter alia, to study the situation of children with albinism in temporary holding shelters in Tanzania and to investigate the impact of armed conflict upon children in Central African Republic and in South Sudan: Sloth-Nielsen 2017a).

Thus far three such studies have been undertaken or agreed, and three special mandate holders are consequently in office (the appointment of one additional special mandate holder, on the Sale of Children, Child Prostitution, and Child Trafficking predates the coming into operation of the CRC) and fulfil aspects of a monitoring role.

The first Special Representative followed the UN Study on Children and Armed Conflict (Impact of Armed Conflict on Children, Report of the Expert of the Secretary General 1996), which led to the appointment of a Special Representative on Children and Armed Conflict. She plays a particular role in relation to the Optional Protocol on the Involvement of Children in Armed Conflict (Sahovic et al. 2013: 354). A second 
functionary is the Special Representative of the Secretary General on Violence against Children, appointed in the wake of the Report of the Independent Expert for the United Nations on Violence against Children. The mandates of both have been extended several times.

The most recent appointment is that of an expert to lead a global study on children deprived of their liberty (who was appointed in 2016). This study will commence in 2017.

There is a specific monitoring mechanism in relation to the use of children in armed conflict which has been established by the UN Security Council pursuant to resolution 1612 (2005). The Security Council Working Group on Children and Armed Conflict reviews reports on violations against children affected by armed conflict committed by parties that are listed in the annexes to the Secretary-General's report on children and armed conflict in what is described as a monitoring and reporting mechanism (MRM). The annexes list parties that recruit or use children in violation of the international obligations applicable to them, parties to armed conflict that engage in patterns of killing and maiming of children and/or rape and other sexual violence against children in situations of armed conflict (in accordance with resolution 1882 (2009)), and parties to armed conflict that engage, in contravention of applicable international law, (a) in recurrent attacks on schools and/or hospitals and (b) in recurrent attacks or threats of attacks against protected persons in relation to schools and/or hospitals in situations of armed conflict (in accordance with resolution 1998 (2011) (https://www.un.org/sc/suborg/en/subsidiary/wgcaac) abduction of children and denial of humanitarian access. These have been identified as the "six grave violations" (https://childrenandarmedconflict.un.org/publications/WorkingPaper-1_ SixGraveViolationsLegalFoundation.pdf).

Parties to conflict listed in the Secretary-General's annual report on children and armed conflict are requested by the Security Council to develop action plans to address grave violations against children. "An action plan is a written, signed commitment between the United Nations and those parties who are listed as having committed grave violations against children in the Secretary-General's Annual Report on Children and Armed Conflict. Each action plan is designed to address a specific party's situation, and outlines concrete, time-bound steps that lead to compliance with international law, de-listing, and a more protected future for children" (https://childrenandarmedconflict.un.org/our-work/action-plans/). According to the Special Representative of the Secretary General on Children and Armed Conflict, "an agreement between Government security forces and the United Nations to end the recruitment and use of children can include the following actions: criminalizing the recruitment and use of children by armed forces and issuing a military order to stop and prevent child recruitment; investigating and prosecuting those who recruit and use children; appointing child protection specialists in security forces; releasing all children identified in the ranks of security forces; providing regular, unimpeded access to military camps and bases so child protection actors can verify that no children are in the ranks; providing release and reintegration programmes for children; strengthening birth registration systems and integrating 
age-verification mechanisms in recruitment procedures; and implement national campaigns to raise awareness and to prevent the recruitment of children."

A party to conflict shall be eligible for delisting only upon United Nations verification that all activities have been successfully implemented. At the time of writing, 26 listed parties had signed 27 action plans, including 11 Government forces and 15 non-State armed groups. Of those, nine parties had fully complied with their action plan and were subsequently delisted. Armed forces and groups in 14 countries remain listed. Thus, in certain circumstances, this form of monitoring by public naming and direct engagement seems to have borne fruit.

\subsection{The UPR Process and Children's Rights}

The Universal Periodic Review (UPR) process has now entered its third cycle (2017-2021). Because it differs so markedly from monitoring by treaty bodies, a brief section is devoted to this human rights mechanism as a form of monitoring and implementation. The UPR is a unique process which involves a review of the human rights records of all UN Member States. The UPR is a State-driven process, under the auspices of the Human Rights Council, which provides the opportunity for each State to declare what actions they have taken to improve the human rights situations in their countries and to fulfil their human rights obligations; it was created by UN General Assembly on 15 March 2006 by resolution 60/251.

The Human Rights Council consists of 47 State representatives of Member States, elected by the General Assembly to be broadly representative of the world regions. Elections are held for one third of the members every year (Sahovic et al. 2013: 378). It is a primarily political body with a comprehensive human rights mandate, and its strengths lie in its periodicity, transparency, and universality (UPR-INFO 2014). The UPR is a form of peer review mechanism, since the recommendations are provided by member states of the Human Rights Council (as opposed to independent experts acting in their personal capacity). States are partly guided by their national human rights priorities when crafting recommendations and heavily rely on efficient cooperation between their permanent mission, embassies, and the capital (UPR-INFO). Another feature is that NGOs and NHRIs in practice play a significant role in providing suggestions for recommendations, and those recommendations which a state under review accepts have a high chance of being implemented at domestic level. Since the process involves all human rights, children's rights appear regularly in the list of recommendations, and the UPR process therefore complements the monitoring undertaken by the CRC Committee.

The reviews are conducted by the UPR Working Group which consists of the 47 members of the Council; however any UN member state can take part in the discussion/dialogue with the reviewed State. Reviews take place through an interactive discussion between the State under review and other UN Member States, lasting 3 and a half hours. During this discussion any UN member state can pose questions and comments and/or make recommendations to the States under review. The review results in an "outcome report," which provides a summary of the actual 
discussion. It therefore consists of the questions, comments, and recommendations made by States to the country under review, as well as the responses by the reviewed State. The reviewed State has the opportunity to make preliminary comments on the recommendations choosing to either accept or note them. Both accepted and noted recommendations are included in the report, which is then adopted at a plenary session of the Human Rights Council.

Some child rights issues which feature regularly at UPR member state reviews include birth registration, trafficking, female genital mutilation, child marriage, and corporal punishment. A fuller study of the impact of the UPR process on children's rights is perhaps overdue, and indeed the high incidence of child rights recommendations during UPR reviews deserves further study.

\section{$5 \quad$ The Monitoring Role of NHRIs}

National Human Rights Institutions (NHRIs) which are statutory bodies independent from the other branches of the State machinery, and their functional equivalents (such as ombudsmen), play a critical part in the reporting process on children's rights. Furthermore, as Ineke Boerefijn noted in 2013, NHRIs play a crucial role in the implementation of human rights at the domestic level. They bring a childoriented focus to what were previously exclusively adult governance systems. "Often offering direct mechanisms for greater accountability of the state and other duty bearers for children, they fill gaps in checks and balances and make sure that the impact of policy and practice on children's rights is understood and recognized. They support remedy and reform when things have gone wrong or results are inadequate." They do not replace the line ministries and government agencies that are responsible for service delivery and the fulfilment of children's rights "but work alongside them to strengthen their performance." Further, they can supplement the activities of nongovernmental organizations working in the children's rights sphere and join or initiate strategic litigation to further children's rights. Independent institutions have direct access to decision-makers. They are usually required to report annually to the parliament and/or the government. On this occasion, they are able to raise the concerns they have heard and investigated on the ground to those who are responsible for preparing, adopting, and implementing laws and policies. While only a handful of such institutions existed in the world in 1996, their number has grown rapidly, as has the involvement of NHRIs in treaty monitoring processes.

Both NHRIs and other independent human rights institutions for children are defined by UNICEF as "[a] public body with independent status, whose mandate is to monitor, defend and promote human rights and which has a focus on children's rights, either as a specialized institution or because it carries out activities specifically focusing on children, with an identifiable department. It can be established at national or sub-national level" (UNICEF 2013: Xi). Human rights commissions have general human rights mandates, extending from promotional and investigative to research and quasi-adjudicative functions. More often than not, NHRIs do not have a 
specific and dedicated child right focus; at the urging of the CRC Committee, many States parties have established a child rights directorate, division, or desk in their respective human rights commissions. Other examples include human rights committees, ombudspersons, and children's rights commissioners, and Europe is especially well served by network of ombuds for children.

The Paris Principles, adopted in 1993, and CRC Committee's General Comment No. 2 (The Role of Independent National Human Rights Institutions in the Promotion and Protection of the Rights of the Child) constitute the central framework for considering NHRIs in the international sphere related to children's rights. The Paris Principles relate to the status of national institutions for the promotion and protection of human rights and were adopted by UN General Assembly resolution 48/134 of 20 December 1993. These minimum standards provide guidance for the establishment, competence, responsibilities, and composition, including pluralism, independence, methods of operation, and quasi-judicial activities of such national bodies. They set forth six essential characteristics for these institutions: independence guaranteed by statute or constitution; autonomy from government; pluralism, including in membership; a broad mandate based on universal human rights standards; adequate resources; and adequate powers of investigation.

The Paris Principles require that NHRIs promote and protect human rights and function independently of government. They note that the scope of work of NHRIs should include lobbying for human rights legislation, publicizing human rights including human rights violations, and education about human rights. The principles stipulate that harmonization of national laws with international treaties is part of the core function of a NHRI, and principle 3(d) spells out that NHRIs shall contribute to reports to global and regional organs and cooperate with UN and regional organizations. This has been further elaborated by the International Coordinating Committee (ICC) Subcommittee on Accreditation in General Observation 1.4 of 2012, which explained that interaction with the international human rights system means "making an input to and participating in these international human rights mechanisms and following up at the national level to the recommendations resulting from the international human rights system" (Boerefijn 2013: 440). The ICC's name has changed to GANHRI (the Global Alliance of NHRIs) and the GANHRI Subcommittee on Accreditation accredits NHRIs as either A status (fully compliant with the Paris principles), B status (partially compliant), or C status (not compliant with the Paris principles, e.g., through being uncritical and not independent of government).

General Comment No. 2 elaborated and harmonized an approach to monitoring children's rights that had hitherto been inconsistent (UNICEF 2013: 21). Par 1 of General Comment No. 2 situates the establishment of NHRIs by States parties within Article 4 of the CRC, the overall implementation clause, although the CRC does not explicitly refer to independent human rights institutions. According to the CRC Committee, every state needs an independent institution able to independently and effectively monitor, promote, and protect children's rights (CRC/GC/2 2002 par 7). Aware of the scarcity of resources in many contexts, the CRC committee proposes the "development of a broad-based NHRI that includes a specific focus on children [that] is likely to constitute the best approach. A broad-based NHRI should include 
within its structure either an identifiable commissioner specifically responsible for children's rights, or a specific section or division responsible for children's rights" (CRC/GC/2 2002 par 6). Independent institutions for children should have broad mandates in relation not only to the state but to all relevant public and private entities, bearing in mind that a wide range of duty bearers are responsible for implementing children's rights. According to UNICEF (2013: 22) the focus on child accessibility and participation is one of the most distinctive aspects of General Comment No. 2.

The CRC Committee's principal concern is that the relevant institutions should be able "independently and effectively, to monitor, promote and protect children's rights" (CRC/GC/2 2002 par 10). Par 20 of the GC envisages that NHRIs "should contribute independently to the reporting process under the Convention and other relevant international instruments and monitor the integrity of government reports to international treaty bodies with respect to children's rights, including through dialogue with the Committee on the Rights of the Child at its pre-sessional working group and with other relevant treaty bodies." Gran (2011:221) stresses the role that ICRIs play in collaborating with NGOs and bridges the divide between government, families, other institutions, and children themselves. Many institutions - a quarter of those reviewed in the UNICEF study of 2013 - have a legal mandate which explicitly requires them to interact with children and seek their views as part of the institution's regular work. Even those with no specific legal mandate to do so have developed child participation structures, such as permanent youth councils (Sedletzki 2016). Critical to success is the geographic and physical accessibility of independent human rights institutions for children (Sedletzki 2016), and various NHRIs and independent institutions have developed various strategies to reach out to children in more remote areas, including establishing local offices at community level and field trips and by using mobile units.

NHRIs are relevant to both monitoring and to implementation. First, information and reports supplied by NHRIs complement the reporting processes to treaty bodies such as the CRC Committee; second, the "outputs" of the NHRIs at the domestic level consonant with the concluding observations of treaty monitoring bodies contribute both to monitoring of children's rights and to implementation of the respective COs. As independent bodies, Boerefijn (2013) argues, NHRIs can play a distinct role in the reporting cycle, insofar as they can be involved in the preparation of state party reports, as well as submitting their own reports. UNICEF notes a significant difference in the approach of the Paris Principles and the CRC Committee's General Comment No. 2: "the former calls on human rights institutions to feed into reporting by contributing to state reports, while the latter stresses the need for institutions to report independently on conditions in their countries, in keeping with their independent monitoring function. While contributing to the official report can be a way to influence its content, alternative reports offer an independent perspective and provide an opportunity for direct interaction with the CRC Committee" (UNICEF, Championing Children's Rights 2013). Boerefijn notes that the Office of the UN High Commissioner for Human Rights describes the relationship between treaty bodies, NHRIs, and State parties as a "symbiotic relationship" in which the main 
duty bearers are in fact the States parties., The CRC Committee, among others, has used COs to address remarks regarding NHRIs, often advocating for them to be strengthened and accorded increased resources to monitor children's rights. In fact, one commentator has opined that the CRC Committee has been the "most relentless advocate" of NHRIs, emphasizing their importance in general comments on various issues, as a general measure of implementation for the Convention, and systematically urging their creation and strengthening in its concluding observations on State parties' reports. It has been found that across regions, the CRC Committee has been the "single greatest driver of the move to establish independent human rights institutions for children" (Sedletzki 2016 quoting UNICEF Championing Children's Rights 2013).

The overwhelming majority of independent human rights institutions for children feature a complaints mechanism, through which they can handle complaints on individual violations of children's rights and mediate a solution. This is all the more important in view of children's general lack of access to justice systems, as they often lack legal capacity to pursue cases, and judicial proceedings are complex and intimidating (Sedletzki 2016). NHRIs and similar bodies more often than not treat complaints with a flexible approach geared toward finding a satisfactory solution such as through mediation; these institutions are usually not able to issue binding decisions like courts (UNICEF 2013: 119). Nevertheless, sometimes NHRIs do also represent the complainant(s) in litigation and sue in their own name or in the name of the complainant(s) or engage in public interest litigation that has no identifiable group of victims (Chirwa 2015).

In the assessment of Sedletzki, "[i]ndividual complaints are a critical instrument for accountability and for closing the gap between children's experiences and formal accountability. They constitute a direct form of redress. They may lead to direct change in state actions concerning a particular case - whether individual or collective. Because their filing and handling follows flexible procedures, they constitute an important child-sensitive mechanism. They also represent a way for institutions to get first-hand information on the challenges faced by children in society and advise on policies to address them" (2016: 17). Chirwa (2015: 35) notes that (in respect of African NHRIs) "most commissions receive and investigate complaints alleging violations of human rights but have limited remedial or enforcement powers. Typically, such commissions receive complaints, advise and assist claimants to seek remedies before other suitable institutions, attempt conciliation and, if that fails, proceed with the investigation and determination...The determinations they make are recommendations and hence, strictly speaking, not binding. These recommendations get enforced through political pressure, political agents such as a minister, president or parliament, or action to enforce its decision through ordinary courts."

At the same time, it must be noted that NHRIs vary widely across the globe in access to resources, effectiveness, sometimes in their degree of independence from government structures, and visibility. Problems identified by Chirwa in relation to the engagement of NHRIs in the children's rights arena (his focus is African NHRIs) is first that a considerable number of NHRIs and child councils have appointment procedures that are too politicized to ensure that these organizations operate in 
dependently or professionally. He advocates that States should consider reforming them in line with the Paris Principles, as the CRC Committee has repeatedly recommended. Second, he opines that NHRIs need to pay more attention to investigating systemic children's rights issues, to engaging in public interest litigation on children's rights, and to engaging with parliamentarians more directly and consistently (Chirwa 2015: 52).

\title{
6 Conclusions
}

This chapter has reviewed an array of bodies and procedures related to the concepts on "monitoring and implementation of children's rights," largely at the supranational level. While the impact of the CRC and the rights it upholds for children have been an undeniable positive force by most assessments (Liefaard and Sloth-Nielsen 2016), there is no room for complacency. As the African Child Policy Forum have recently pointed out (ACPF 2016: 26):

\begin{abstract}
There is a widespread under-estimation of the demand for effective child rights implementation among policymakers and practitioners. The complexities and challenges of child rights implementation have also been hugely under-estimated in the African context, both by governments and by the child rights communities in other sectors. Many fail to see that implementation is a long and protracted process that requires unwavering commitment; and there is often limited awareness of what constitutes effective implementation, and the inputs required to get the process right. Implementation requires sustained political and budgetary support over a long period of time before considerable progress can be made and concrete results achieved. Reaching an understanding of the complexity and underlying challenges, as well as the cost and resources required, is a critical step: such awareness helps policymakers make adequate preparations before they embark on reforms to address the problem.
\end{abstract}

There have been undeniable advances in recognizing children as bearers of human rights. In particular, children's participation rights have developed by leaps and bounds since the adoption of the CRC, and children's voices are increasingly being heard in many domestic systems. The recognition of the pervasive violence experienced by children, and the need to address this, has also confirmed their status as beneficiaries of all human rights. But while millions of children die unnecessarily each year from preventable diseases, suffer untold harm during armed conflict, languish needlessly in detention, and embark on dangerous migratory journeys, there can only but be room for improvement in the monitoring and implementation of children's rights.

\section{References}

African Child Policy Forum African Report on Child Wellbeing (2016) ACPF Addis Ababa)

Arts K (2014) Twenty-five years of the United Nations Convention on the Rights of the Child: achievements and challenges. Neth Int Law Rev 61(3):267-303 
Boerefijn I (2013) Partnerships between National Human Rights Institutions and Human Rights Treaty Bodies in the implementation of concluding observations. In: Haeck Y, Leyh B, Burbano-Herrera C, Contreras-Garduno D (eds) The realisation of human rights: when theory meets practice- studies in honour of Leo Zwaak. Intersentia, Cambridge

Child Rights Connect. Available at http://www.childrightsconnect.org/

Child Rights Connect. The reporting cycle of the Committee on the Rights of the Child: a guide for NGOs and NHRIs (NGO Guide)

Chirwa D (2015) Monitoring and accountability mechanisms for the implementation of children's rights in Africa. Working paper commissioned by the African Child Policy Forum

Committee on the Rights of the Child (2002) General comment no. 2 (CRC/GC/2002/2) the role of Independent National Human Rights Institutions in the promotion and protection of the rights of the child

Committee on the Rights of the Child (2005) General comment no. 5 (CRC/GC/2003/5) general measures of implementation of the convention on the rights of the child

Committee on the Rights of the Child (2010) Concluding observations Sudan (CRC/C/SDN/CO/3-4) NGO submission guide. Available at http://www.ohchr.org/Documents/HRBodies/CRC/ GuideNgoSubmission_en.pdf

Committee on the Rights of the Child (2012) Concluding observations Madagascar (CRC/C/MDG/ $\mathrm{CO} / 3-4)$

Committee on the Rights of the Child (2014) Working methods for the participation of children in the reporting process of the Committee on the Rights of the Child. United Nations, Geneva, 16 Oct 2014

Committee on the Rights of the Child (2015) Treaty specific guidelines regarding the form and content of periodic reports to be submitted by States parties under article 44, paragraph 1 (b), of the Convention on the Rights of the Child. United Nations, Geneva, 3 Mar 2015 (Revised Reporting Guidelines)

Committee on the Rights of the Child (2016a) General comment no. 19 (CRC/C/GC/19) public budgeting for the realization of children's rights (art. 4)

Committee on the Rights of the Child (2016b) Concluding observations South Africa (CRC/C/ZAF/ $\mathrm{CO} / 2)$

Committee on the Rights of the Child (2017) Concluding observations Cameroon (CRC/C/CMR/ $\mathrm{CO} / 3-5)$

Committee on the Rights of the Child CRC Rules of Procedure, UN Doc. CRC/C/4/Rev.3, 16 Apr 2013

Committee on the Rights of the Child Working Methods. Available at www.ohchr.org/EN/ HRBodies/CRC/Pages/WorkingMethods.aspx

Gran B (2011) The roles of independent children's rights institutions in implementing the CRC. In: Invernizzi A, Williams J (eds) The human rights of children: from visions to implementation. Ashgate Publishing, Farnham, p 221

Heyman J, McNeill L (2014) Assessing compliance with the CRC: indicators of law and policy in 191 countries. Int J Child Rights 22(3):425

https://www.unicef.org/infobycountry/china_statistics.html

https://www.unicef.org/infobycountry/vanuatu_statistics.htm

Krommendijk J (2014) The domestic impact and effectiveness of the process of state reporting under UN human rights treaties in the Netherlands, New Zealand and Finland. Paper-pushing or policy prompting? Intersentia, Antwerp

Krommendijk J (2015) The domestic effectiveness of international human rights monitoring in established democracies. The case of the UN human rights treaty bodies. Rev Int Organ 10:489. https://doi.org/10.1007/s11558-015-9213-0

Liefaard T, Sloth-Nielsen J (eds) (2016) The United Nations Convention on the Rights of the Child: taking stock after 25 years and looking ahead Brill publishers, The Netherlands. ISBN 9789004295049 
Lundy L, Kilkelly U, Byrne B (2013) Incorporation of the United Nations Convention on the Rights of the Child in Law: a comparative review. Int J Child Rights 21(3):395-441

Mechlem K (2009) Treaty bodies and the interpretation of human rights. Vanderbilt J Transl Law 42:905

O'Flaherty M (2006) The concluding observations of United Nations treaty bodies. Hum Rights Law Rev 6(1):27-52

Office of the High Commission for Human Rights. Guidance note on constructive dialogue A/69/285

Office of the High Commission for Human Rights Guidelines on the independence and impartiality of members of the human rights treaty bodies ("the Addis Ababa guidelines") A/67/222

Office of the High Commission for Human Rights. National mechanisms for reporting and followup - a practical guide to effective state engagement with international human rights mechanisms (HR/PUB/16/1)

Office of the High Commission for Human Rights. Strengthening and enhancing the effective functioning of the human rights treaty body system. A/Res/68/268 of 21 Apr 2014

Organization of African Unity (OAU) (1990) African Charter on the Rights and Welfare of the Child, 11 July 1990, CAB/LEG/24.9/49. http://www.refworld.org/docid/3ae6b38c18.htm

Polonko K, Lombardo L, Bolling M (2016) Law reform, child maltreatment and the UN Convention on the Rights of the Child. Int J Child Rights 24(1):29

Report of the Expert of the Secretary General (1996) Impact of armed conflict on children UN Doc $\mathrm{A} / 51 / 306$

Report of the Independent Expert for the UN study on violence against children GA Res 60/231

Report of the Secretary-General (2016) Status of the Convention on the Rights of the Child A/71/150

Rishmawi M (2006) Article 4: the nature of states parties' obligations. In: Alen A et al (eds) A commentary on the United Nations Convention on the Rights of the Child. Marthinus Nijhoff Publishers, The Hague

Sahovic N, Doek J, Zermatten J (2013) The rights of the child in International Law. Stampfli Publishers, Berne

Save the Children International and Dullah Omar Institute, University of the Western Cape (Forthcoming) Handbook on the implementation of the African Charter on the Rights and Welfare of the Child

Sedletzki V (2016) Closing the gap between social and formal accountability: exploring the role of independent human rights institutions for children. In: Liefaard T, Sloth-Nielsen J (eds) 25 years of the CRC: taking stock and looking forward. Brill, The Netherlands

Simmons B (2009) Mobilizing for human rights. International law in domestic politics. Cambridge University Press, Cambridge

Sloth-Nielsen J (2015) Implementation of children's rights: a study of what is required in selected theme areas. Working paper commissioned by the African Child Policy Forum

Sloth-Nielsen J (2017a) The African charter on the rights and welfare of the child. In: Boezaart T (ed) Child law in South Africa, 2nd edn. Juta and Company, Cape Town (forthcoming)

Sloth-Nielsen J (2017b) Child justice. In: Boezaart T (ed) Child law in South Africa 2nd edn. Juta and Company, Cape Town (forthcoming)

Special Representative of the Secretary General on Children and Armed Conflict Working Paper1. Six grave violations- the legal foundation. Available at https://childrenandarmedconflict.un.org/ publications/WorkingPaper-1_SixGraveViolationsLegalFoundation.pdf

Spronk van der Meer S (2014) The right to health of the child. Intersentia, Cambridge, UK

Stein J (2016) The prevention of child statelessness at birth - the UNCRC committee's role and potential. Int J Child Rights 24(3):499 at 512

Theytaz Bergman L (2007) NGO reporting under the Convention on the Rights of the Child, conference presentation Amsterdam

UN General Assembly, Vienna Declaration and Programme of Action, 12 July 1993, A/CONF.157 / 23. http://www.refworld.org/docid/3ae6b39ec.html. Accessed 1 May 2018

UN Working Group on Children and Armed Conflict. https://www.un.org/sc/suborg/en/subsidiary/ wgcaac. Accessed 7 Feb 2017 
UNICEF Innocenti Research Centre Law Reform and Implementation of the Convention on the Rights of the Child. https://www.unicef-irc.org/publications/493-law-reform-and-the-implemen tation-of-the-convention-on-the-rights-of-the-child.html

UNICEF-IRC (2008) Law reform and the implementation of the convention on the rights of the child. Available at https://www.unicef-irc.org/publications/pdf/law_reform_crc_imp.pdf

United Nations Children's Fund (2013) Championing children's rights: a global study of independent human rights institutions for children. UNICEF Office of Research, Florence

United Nations Children's Fund Law Reform (2007)

UPR-Info. The butterfly effect. Available at https://www.upr-info.org/sites/default/files/generaldocument/pdf/2016_the_butterfly_effect.pdf

Van den Hole W (2014) Children's rights from a legal perspective in Routledge international handbook on children's rights studies. Routledge, New York

Wallace R, Martin Ortega M (2013) International law, 7th edn. Sweet and Maxwell, London 